\title{
Leadership Influence in Learning
}

\author{
Ibitoye Rachel Adeola* \\ Faculty of psychology and Education Science, University of Bucharest \\ *Corresponding author: udzee001@gmail.com
}

Received June 12, 2013; Revised February 27, 2014; Accepted March 17, 2014

\begin{abstract}
A very good and functional way to measure the value of any learning process is by taking into consideration and also utilizing the impact the process as a whole has had on the learner, his society, his economy, his organization and also the level at which more knowledege can be generated. Nowadays, with the level of exposure that we have through the help of science and technology, learning can be done through many different means. However the different ways through which learning can occur can be summed up into these four circumstances, being Education, Self discovery, Experience and Discussions. As mentioned earlier the disposable availabity of science and technology in our todays world simply goes to emphasis the importance and neccessity for not just Teaching but at the same time Learningto occur. Nonetheless for this two processes to occur in such a way that it would be easily said that a learning process has indeed taken place, there's a dire need for what we can refer to as Effecting Leadership: A role played by the teacher, and alongside, Willful Learning: A role apparently played by the learner. A leader, as much as he has the abilities and powers to Influence his subordinate positively also with the same magnitude can influence the same subordinate negatively. Nevertheless, before going into how this can happen or what circumstances can bring about such divastating results, it is of optimost importance that I highlight with clarity the meaning of the key words in this paper work, so as to enable us have a good understanding of not only the theme but as well as the major aim of the paper, which is tobring to light and in clear terms too, the types of Leaders that can Influence their learners and their immediate environment in the most positive ways. This can be said to be the most important focus of this Paper.
\end{abstract}

Keywords: leadership, influence and learning

Cite This Article: Ibitoye Rachel Adeola, "Leadership Influence in Learning." American Journal of Educational Research, vol. 2, no. 3 (2014): 173-182. doi: 10.12691/education-2-3-11.

\section{Introduction}

Leadership: It is no news that leadership as a word can be very and as a matter of fact extremely diffucult to define. Therefore rather than giving it a direct and most likely unfouded definition, it would be much better to gain an understanding of what exactly it entails by deriving a conclusion after putting into consideration several profound definitions.

Wikipedia decribes"Leadership as the process of social influence in which one person can enlist the aid and support of others in the accomplishment of a common task”.

It goes futher to give the description of Alan Keith, who thinks "leadership is ultimately about creating a way for people to contribute to making something extraordinary happen”.

A third and even simpler definition descrides leadership as influencing a group of people to achieve a common goal.

From these three definitions of leadership, it is therefore fair to conclude or sum up that Leadership firstlyis a word that cannot be meaningful in isolation and it's difficult to explain the meaning without followership. Thus in summarazing the need for social influence, support and achieving a common goal, Leadership for this particular paper work can therefore be described as the "process" with which a Leader(an Individual or team) sets out to achieve the common goal of a set of people by the use of social influence.

In an attempt to gain a clearer image of what truly leadership encompasses, one can take to mind very simple and common life examples of how very little things act as leaders. The door to a house for example is the one legitimate way through which the beauties and qualities of a house's interior can be explored. In the same light, a leader is the way through which the hidden qualities and beauties of a given set of people determined to achieve a common goal can be explored. This house might be a one bedroom apartment, probably a 7 bedroom mansion or even a 15 bedroom palace, whichever or whatever it is, it's outrightly undebateble that without a way(the door) inside, no one can get to see what treasures this house holds. This is the very same reason why doors exist right from the paper plan of the house. Yet again, so also does a leader serve as the entrance and the medium that guides his followers to achieve their common goal.

With the use of such a simple and direct illustration of Leadership as being the "WAY", one can easily misconcept leadership to very simple, direct and straight to the point. But in real case scenario, it can prove to be slightly more complicated than the door that opens the 
way to beautiful treasures. When for example one takes a look at a Primary educational institutions, a primary school to be precise, one can experience and gain an even better understanding of how the process of leadership actually unfolds. The principal or the school director is seen as a leader of this particular institution. Coupled with this overall leader are the sub leaders, which comprise of the Vice Principal or Deputy Director, the Head of departments, the Class Teachers the Subject Teachers and even the Class heads, Class monitors or Class prefects as the case may be, all of which are leaders in their own jurisdiction.While being leaders, in so many different ways, these authorities also happen to be learning. As message and intructions are passed on from the director to his Vice, a lesson or two is also taken on how to ensure efficiency is paramount. Ultimately, we can derive that the efforts and level of organisation of all this leaders plays a very important role in seeing to it that learning as a process takes place, this learning can be either direct or indirect.

In an organisation such as a primary school, there is a serious and despirate need for efficiency in all endeavours and changes need to occur for progress to me made. Changes such as the development of the teaching skills available, the receptiveness of the students, but even more importantly the medium and system of communication that exists between both the teachers and the learner.

For example, a class of ten student would have an entirely different style of communication compared to a class of 45 students if any form of efficiency and productivity must be resultant from these students. A leader in such a scenario must thus be capable enough to Direct both teacher and student into a state of mind that encourages easy and productive communication.

\subsection{Charity Begins at Home}

Every society no matter how large or small comprises of various units, the smallest of which is a Nuclear Family. As a matter of fact, it's a found saying that "no society can't exist without families".

For clarification's sake a family in this case can simply be described as a group of people related by blood, and a nuclear family is one that comprises mainly and only of the Father (the head or leader), the Mother and Children.

The family being the fundamental structure or in otherwords the foundation of a society or community, plays a very important role in safeguarding that the community as a whole turns out to be a highly productive one through the maximal utility of the good leadership available at its disposal. In a situation whereby the product of a family is unproductive, it's effects on the society are adverse and often brutal. However such cases do not exist without causes or negative motivaton. The question now is, how can a family member stand as such a liability or detrement to his society? And what circumstances bring about such unproductive societal liabilities.

In our world today, we can pick out several examples of how a family member can serve as such a liability. Giving the fact that learning as a process plays a very important role in the development of a community, a family member without the ability to do so might as well be considered Useless by his society. In a different situation, a family member with the ability to learn, but unwillingness to do so can again, be considered useless by his society. Numerous cases very similar to these two are seen in our educational systems today, where students asides from being mentally incable of learning, do not have the attitude, patience and desire to do so.

The answer to the question, "But Why?" is what leads us to the sub-title of this column... Charity begins at home. In literal terms this phrase would mean; for an individual to be kind to his neighbours, friends and associates, he first needs to have the plane ability to show kindness to those closest to him... His Family. Nevertheless, just like learning, charity is a two way trafficked phenomenum which has to do with giving and taking. When a father gives and recieves respect to and from his child and wife, he can practise such a gesture with his work mates. Like wise when a child recieves and gives love from and to his parents, he can practise the process with his class mates. Thus the practice of gestures and life styles that would help boost societal development in homes is what is needed for such gestures to be inbibed into that community.

More precisely now though, for a child to develop a learning spirit, it is essential that his immediate environment creates an avenue through which learning takes place on a daily bases. His family in other word must have the will to certify that simple learning principles are very well understood by their member. Principle such as Listening, Observing, Perceiving, Participating and asking questions when the need arises. When these type of enviroment is absent, there lies the tendency of creating an individual with such a deformity and lack of value to his society.

If we therefore stand in accordance that the family is the the foundation of a society, and that no building can be completed or even get underway without a solid concrete foundation, we can as a result establish that effective and adequate response to good societal leadership can only exist when, the foundation of that society (the family) itself pratises good leadership in all ramifications. When such a solid foundation is built, it's inevitable that this society can flourish, through the combination of these very small units which have put in the effort to practise leadership and followership in their own jurisdiction.

\subsection{Educational Outcome}

The educational outcome of a country or society in general is another way through which the concept of good leadership can effortlessly be understood. In the sense that, for profit to be made, quality investments must be made. Taking to mind the latest world top 200 university rankings (2011), it can be observed that only the universtiy of Capetown South Africa represented Africa on the chart with the position of $107^{\text {th }}$. The passion I have for Africa is unquestionable, but this is not just the reason I'm always on the look out for it. As a matter of fact, the world is on the look out for Africa. This is because of the humongous amout of resources it posses. This in no way however, has been a motivation for it's educational system, as it struggles rigorously to meet up with our today's world class educational standard.

Coming from Africa, this is no news to me, because I understand that If "out of date" knowledge are refurbished and updated, and obsolate teachers were given necessary 
benefit and replaced with brand new ones who are passionate and determined to succeed in their various fields, then the performance in Africa would be just as good as any where else in the world. Unfortunately, that isn't the case.Instead we have situations where countries like where I'm from (Nigeria), in the midst extremely divastating educational conditions, pride themselves with slogans such as "Giant of Africa". We have an Africa whose giant prides over a Tetiary educational system that finds no place in the top 30 universities in Africa. Incredible agonizing I must confess, yet again, it is certain that if adequate research were being carried out and teachers who have global pursuits are used in training learners, the educaitonal outcome would surely put smiles on the faces of the learner, educational leaders and the society as a whole.

It is thus the responsibility of the leaders in Africa to generate scenarios where teachers of this manner can be put to work. The quality of leaders in Africa, sadly do not match up to this responsibility. This brings me to...

\subsection{Characteristics of a Good Leaders}

Good leadership in this modern age importantly requiresattitudeesand behaviourswhich characterise and very well relate to humanity. Almost every life endeavour requires a tangible quantity of know how and skill to triumph, it doesn't just stop at having the know how and skill though, there should also be the willingness to apply this know how and skill before success can really be achieved.

Leadership however is entirely just about basically utilizing skills and knowledge, this is because it's a process that encaps a lot of emotions, trials, and mental challenges all in one. Consequently a Good leader calls for an individual with emotional strengths and behavioural characteristics who can draw deeply from his mental and spiritual reserves.

The leadership role today is an inevitable reflection of peoples needs and challenges in this modern life. Leadership is therefore a profound concept, with increasingly complex implications, driven by an increasingly complex and speedily changing world.

In our world today, an individual who is striaght to the point, strict and brutal can be a leader. However it takes so much more than a good sense of direction to be a good leader. Good leaders are followed chiefly because of the trust and respect their followers have in them, rather than the skills and knowledge they posses. As a result we can establish that in leadership, Behaviour comes first, after which comes the utilization of the skills and knowledge possessed. The effective combination of these two, which is, to with a good behaviour, utilize the knowledge and skills possessed is what distinguishes between just any leader and a Good leader.

Kindly permit me to re affirm the crusial need and importance of good leaders by the use of this business inclined illustration. In business the packaging of a commodity is extremely important. This is for the reason that a customers first impression of a product or commodity goes a long way in determining whether or not he'll purchase that product. Asides from this, the quality of time, effort and energy put into packaging a product is also very easily reflected on the final product and it goes a long way to determine the market value of that product. Given that there is an established classmate and measurement of packaging quality in a market, If your product is packaged as a second rated product it will be the valued at a second rated price or even less. On the other hand, if you give it a first class packaging there is a higher tendency for the market to respond in the same manner.

For such inspiration to exist in a business conversely, there's a need for a GOOD leader. One with a vision and a clear understanding of what he wants for his business. That business needs a manager that can channel his vision through to his staff, and can influence them in effective ways that can motivate them to reach their highest potentials.

Apple Inc. for example, is a very popular electronic company whose late Chief executive offcer Steve Jobs is often said to have CHANGED the world with his magnificent innovations. Apple Inc. had always been around, and had looked to competing with the likes of Microsoft in the early computer days. But it failed outrightly because it was lacking a good manager. On the return of it's former CEO Steve Jobs, the company experienced an incredible upgrade, which led to the repackaging and the re-branding of their products. Today Apple products are used all over the world, it's making life incredibly easier for billions of people, and as a company, it's worth over 30 billion US dollars. This is an excellent example of how important it is to have good leaders in our society today.

What are some of these characteristics or behavioural qualities possessed by a good leader?

\subsubsection{Dedication and Commitement}

Setting out prioritiesin the right order goes a very long way in enabling us to stay committed to every vow we take in life. Dedication and Commitement are two different words but with literally the same meaning.They both are an act of wholly and earnestly devoting to a precise cause, be it a person, group of people or circumstance. The act of binding oneself intellectually and emotionally to achieving a set of goals is how we can easily decribe these two very similar words. Looking at successful athletes, one can attain a solid precept of dedication and commitment in it's real depths. In their attempt to win the gold, silver or bronze medal, they deny themselves of a lot of comfort. They trian right from the break of dawn till even tide. They eat on diet, doing away with carbohydrate and bringing in a lot of vegetables into their daily meals.

When the time finally comes for them to compete, they shut out every other thing that doesn't relate to the task ahead of them. Neither the elated fans chanting their names, not their determined counterparts preparing themselves, gets to have any relevance to them at that point in time. They ensure they are not distracted by even the slightest crack. We can borrow a lesson or two from this about a good leader. If a good leader has such a mind set, and such abilities to focus only on what's important, then there is a chance for such qualities to reflect on those learning from him. This is why we can confirm the importance of dedication and commitement in building a good leader. Because for dreams to come through, for success to be achieved, there's a need for the all the right 
moves to be made. For a learner or a follower to gain from his leader, the leader must be dedicated to making sure that happens. Teaching must be his main goal, and he must be committed to putting in everything he can offer to ensuring that his followers LEARN.

\subsubsection{Integrity}

Integrity is one highly essential quality of a good leader which we don't often find in world leaders today. The importance leaders give to their names nowadays is nothing to write home about. Leaders erase the fact that perceptions about them would always be derived by the people based on their actions as leaders. Sadly, especially in the political sphere and in so many other regions as well, the need to satisfy the associate minority drive leaders into actions which straight way bring shame and woe on them. Intergrity is the quality of a leader that enables him to at all times to do the right things.

When a group of followers cast their trust in a leader, it's very necessary for that leader to prove them right. The act of leading comes with various challenges, which brings the need for a leader to be very well principled, but most importantly, to follow his principles. Also, a leader with integrity is one who gives value to the Truth.

The need for leaders with integrity in our communities today, cannot be over emphazised and the reason for this is very clear. Earlier on we had established that a leader is the gate way through which the treasure and good qualities of a group of people can be explored. We affirmed this by illustrating the usefulness of doors in buildings. If this is thus a responsibility of a leader, it is extremely important that a leader maintains a certain level of composure, by living an examplary live for his followers. When a leader over and over again proves himself to be worthy of his follower's trust, it is inevitable that even in times of despair, he'll have the confidence of a people who he has practically influenced through the life he lived.

\subsubsection{Humility}

Humility is another highly important characteristics of a good leader.Jesus Christ, one of the greatest and most powerful teachers of all time, who still, till this very day has a magnanimous amout of followers and believers world wide, is one outstanding example of how humble a leader should be. In his times, over 2000 years ago Jesus was called Master by those who were older than him, and those who were supposed to have more knowledge than him. He was a man who even the pharisees (the most intelligent men in ancient Isreal) had a great deal of respect for because of his knowledge of the Law and his interpretation likewise. He gave teachings that had never been given, and interpretations of the Law that had never been thought of. He stood as a fufilment to majority if not all of the prophesies that had been made hundred of years before he was born. He had powers that could submount nations and continents just by voicing out his wish. The records of his immense and numerous works truly show and proves him to have been probably the most powerful man to have ever lived.

Even still, he was humble enough to serve his followers. At the last supper(the last meal he had with his followers before being crucified) he laid an extraordinary example for his followers to emulate. Jesus took bread, blessed it, broke it and gave it to his disciples to eat. (Matthew 26:26). He also took a cup of wine and gave them to drink from it (Matthew 26:27), he did this in an attempt to make them understand the importance of unity amongst them."Expri de cur" Stating that both the bread and wine represented his body and blood and eating together meant they had a part with him. After serving them, he encouraged them to do the same to their followers when they become leaders. Today, this gesture is being practiced in almost all christian denominations and stands till today as the very one gesture that units christians all over the world. Love is reciprocal, whatever you give, it is fundamental that you will get it back. An idiomatic expression says; when you point a finger at someone, you point four at yourself.

Humility is said to be the act of being modest and respectful. Jesus' gesture in this case, undoubtedly stands out to be one of absolute modesty and respect for his disciples. We can therefore make this conclusion of humility as being a characteristic of a good leader, from our illustration of Jesus, the living prove of the quality and manner of leadership he displayed and the definition of the word Humility itself that, as important as it is for a leader to be principled, mentaly agile and strict, he must even in his position of power have respect for his followers.

\subsubsection{Courage}

The spirit of an achiever never gives up even at the point of great disappointment.Average human souls always consider failure to be the end and absolute confirmation that their truimph in a particular endeavour is impossible. Considering the nature of failure itself, such a reaction is very well justified. It's a terribly divastating feeling to anticipate success in an endevour so despirately and in the end have your hopes and aspiration cast down. For this reason alone, the decision to completely terminate and get rid of anything that has to do with such an endevour is take. On the contrary, Failure is not an indication that the road to achieving success is ended, it is simply just the opposite of succeeding. As an individual, I consider failure in whateve a stepping stone to actually acheiveing the goal or goals I intially set out to accomplish.

Courage is an individuals ability to willfully confront fear, danger, intimidation, uncertainty and every other vice that can stand against his success. Failure brings about fear, inferioty brings about intimidation and uncertainty, and circumstances come with their dangers. The natural reaction to a fearful situations is for one to fear, the same goes for uncertan situations and so on. But an abnormal action is that of courage, which every good leader should posses.

I do envy the life of miners, and the courage with which they live by from day to day. Not so many people would be set and ready to go to the places miners go to in their bid to find valuable items like gold, petrol, silver, diamonds and so on. The believe they have in their abilities is exceptional, and even in times when they do not come find valuable items from the site they have been working on, they try again the next day, regardless of the failure that might had confronted them the previous day.

In the process of leader, massive challenges will arise, challenges that would test the integrity of a leader. 
Problems that would utterly destroy the self confidence of a leader, In some cases there are slightly less intense challenges. It is however inevitable for challenges to rise. But when they do arise against us as leaders it is essential we use wisdom to handle these challenges. To aquire this wisdom, you must have the patients and believe that thing will be ok, even when they are terrible and disturbing. There must be the will to take action immediately. This is the type of fearlessness needed to solve various challenges as a leader.

\subsubsection{Compassion and Sensitivity}

The Eagle is a wild bird, and a symbol of strength and power. It is a very rigid animal that thrives over ever other beast of the air. Its wings are very poweful and can be as long as 7 feets or even longer. It's rule of over its domain is unquestionable and firm in all senses. When it flies, it soars high to the highest skies and moves majestically in the midst of the clouds. As an eaglet though, it never had all these abilities. It was thought by a compassinate eagle or falcon(female eagle) to fly, but in a very practical way.

When an eaglet is born, it's falcon protects it with everything she's got, with her power, her strenght and all might in her possession. She goes out in the day to fecth food, and wraps him up at night to keep warm. After a period of time, she sets out to teach him how to fly like an eagle. She casts him out of the nest into the skies, to survive. Without mercy and without care for whether or not his wings will carry him. But on noticing the intensity of his free fall, she sets out so compassionately to carry him on her wings, help him feel the glory of the blue skies, and yet again drop him to see where his weaknesses lie and where his strengths stand.

Likewise, as much as a good leader is rigid and strict enough to train his followers, he must also be sensitive and compassionate enough to help in the process of learning. The more sensitive and compassionate a leader, the easier it is for him to understand the needs of his followers and the resultant actions needed to meet their needs.

\subsubsection{Viable}

Leaders must be Viable. As we progress in life we move from the known to the unknown. Learning will go into extintion if leaders are not viable. The word viable means to have capability to reproduce. To reproduce any crop, plant, animal, or child you must have a viable seed of the breed. To be able to lead the children of today to become great leaders of tomorrow they must pass through the hands of viable(productive) leaders. The wheels driving the world to acheiving its set of goals and objectives is in the hands of a good leaders.

All these are but a few of the numerous and very important traits that a leader must potray to be regarded as a good leader.

People who want to be a leaders need to develop their leadership ability. Good leaders typically have a keen understanding of relationships within quite large and complex systems and networks. This may be from an intuitive angle, or a technical/learned.. A British government initiative surfaced in March 2008, which suggested that young people should swear an oath of allegiance to 'Queen and Country', seemingly as a means of improving national loyalty, identity, and allegiance.(5)
While packaged as a suggestion to address 'disaffection' among young people, the idea was essentially concerned with leadership - or more precisely a failing leadership.

The idea was rightly and unanimously dismissed by all sensible commentators as foolhardy nonsense, but it does provide a wonderful perspective by which to examine and illustrate the actual important principles of leadership:(5)

\subsection{Leadership Professional Learning}

Learning as it is often said is a life long endevour. Right from the day fertilization takes place life begins, and at that very moment so does learning begin. From that initial process of life, in very little bits growth is experienced and along side this growth learning also takes place. This growth continues through out the life time until the very day when the person leaves the land of the living by the means of death. In that same manner we can say that learning is a continuous process until death comes knocking. To help create a clearer image, we can take a quick look at the life of an unborn who naturally learns, right there in his mothers womb to find comfort. With the knowledge it(the unborn) has of discomfort and it's understanding of the displeasure it feels when in a state of discomfort, it positions itself in such a way that it can easily derive pleasure rather than displeasure, utilizing to the best of it ability the space available in its mother's womb.

At an entirely different stage of pregnancy, a mother can also feel the kicking of her babing, this is an action the demands a certain amount of knowledge to be carried out. When the baby if finally born, the first thing it does is cry, this is it reaction to the recognition of a change of environment or in simpler terms the fact that a place in which it has become used to over a period of nine months has all of a sudden changed into something it completely has no idea of.

What can we gain from all of this? We can understand that, even from that very minute stage of life, aquistion and utilization of knowledge takes place.

On a larger scale when this child becomes mature enough, a higher and even more intense form of learning takes place, where he or she has to go through primary, secondary, tetiary Education and even what we might refer to as... "the school of life".

Taking an example from my personal experience, I observed that when cell phones were introduced into my country in the year 1999, most people had absolutely no idea what a computer was and how useful or not it could be to the society, including myself. To make anything work by the means of such advanced technological strategy was nothing short of a dream. But on the introduction of such an advanced technological device into our slightly ignorant enviroment, I was baffled at the smoothness and the ease with which the device operated, and following the availability made for computers into the countries system, I felt the need, but ultimately the challenge that was ahead of me. Which was fundamentally to gain a tangible amount of knowledge about how not only the cell phones(mobile device) worked, but how an even more complex and more advanced device(the computer) might be benefitial to myself, my family and my society at large.I thus decided to go for a computer training. Unfortunately my own children were the first to 
pose the question of what I'd like to use the knowledge gained from this training for? But adamantly I responded by making them understand the fact that "no knowledge gained is waist”.

From this training, I was able to acquire a little basic and vital knowledge about computer usage. Simple computer knowledge such as booting and shuting down a computer changed from being a classical movie to plane and tangible skills I had gained. This very little step encouraged my collegues at work to also apply for such computer courses which ended up giving them the same invaluable basic computer knowledge I had.

On my part, learning how to search for information on the internet, sending emails and browsing the internet in general, as basic and as common as it might sound has gone a long way in aiding and contributing to the success of my current program at the University of Bucharest. This has thus re established to me the proverb which says, “Common sense isn't common”.

Another very common saying where I come from says that “a Stagnant water Produces a Fowl smell”. If you read only the words that start with capital letters in that saying, you'll have... Stagnant Produces Fowl, which can simply be interpreted as, nothing good comes out of being stagnant. In this case, the most profitable phenomenum is Malaria, because in the real sense of it, the home for the mosquito larvas that carry the virus are large bodies of Stagnant water.

What exactly is it I'm trying to establish by sharing this experience of mine with you and my use of this illustration. I'm trying to establish that asides from the fact that Leaders play a critical role in guiding the learners through the learning process, they must be able to couple this by actually learning themselves. An educational instructor who believes that there's no need for professional training can as well be considered to be "Stagnant water", because he promotes the idea that there's no need for development.If eventuallythe teacher should abandon aquiring knowledge(learning), over a period of time the knowledge he has would become obsolate and no longer relevant in comparison to the developments taking place in that society and the world at large and this would in turn have a drastic and terrible effect on his surbodinates. Therefore, for a Leader, to keep up with Global movements and advancements and to be in a solid position to dish out high quality knowledge that can serve as a benefit to the society as well as boosting the ongoing development of our world today, it is essential for that leader(no matter what aspect he supervises) to be trained and then re-trained. I believe that all educational instructors, including all the administrative staff who geniunly have concerns about positive learning need Developmental Training.

\subsubsection{Type of Leadership}

There are three major types of leadership. They are autocratic, democratic and laisser-faire.

In 1939, a group of researchers led by psychologist Kurt Lewin set out to identify different styles of leadership. While further research has identified more specific types of leadership, this early study was very influential and established three major leadership styles. In the study, groups of schoolchildren were assigned to one of three groups with an authoritarian, democratic or laissez-fair leader. The children were then led in an arts and crafts project. Researchers then observed the behavior of children in response to the different styles of leadership” Lewin's Leadership Styles

Autocratic leaders: Is the characteristic of an absolute ruler. It is a system of leadership where a single leader is in control of all power. His commands must be obeyed. This system of leadership is obtainable in the military. Autocracy is the type of leadership that provides clear expectations and instructions of what is to be done, the time it should be done, and the manner in which it should be done. This is an absolute rule of a ruler that cut a clear division between the leader and the followers. Authoritarian leaders make decisions independently with little or no contribution from the rest of the group. Authoritarian leadership never considers the consiquence of his command but his basic focus is that his set goal and objectives must be achieved even at the discomfort and displeasure of the followers.

Democratic leadership or Participatory leadership; It is the type of leadership that is directed solely by the decsion of the people. The decision of the people is binding on the society.As the name implies this is the type of leadership by the people and for the people. It is a type of leadership that offers guidance to its followers. It is a system that looks basically to upholding the desire of the followers, as a matter of fact, their needs as a people is the fundamental goal of such a leader. Due to the fact this type of leadership gives room for team spirit work and allow for better quality product it is often more acceptable and has a high potential to be much more effective than any other form of leadership.

Laissez faire: It is the type of leadership with minimal restriction. There are other various sub set of this type of leadership type such as emerged leadership, imposed leadership, team leadership but to mention a few.

Everybody enjoys music, but to produce melody two or more sounds must be produced in an agreeable manner before it can be enjoyed. To produce a good leadership, the three type of leadership styles must be combined in adequate proportion as the case demands to produce good leadership.

\section{Learning}

"Learning is the lifelong process of transforming information and experience into knowledge, skills, behaviors, and attitudes".By Jeff Cobb

Jeff Cobb also stated the following about learning: It is not dependent upon classes and courses - though these can be very useful tools for learning. It does not require a degree, certificate, or grade to prove its worth - though clearly these have social value that most people would be unwise to ignore. It does require - in varying degrees, and in varying times and circumstances - activities like practice, reflection, interaction with the environment (in the broadest sense), and social interaction. The latter, in particular, can be greatly facilitated by the range of new technologies for communication and collaboration now available to us.

It does not always - probably not even most of the time - happen consciously - though I think that those who strive for a more conscious approach to learning 
throughout their lives - whether at work or otherwise tend to be more successful in pretty much whatever way they define success.

\subsection{Reason for Learning}

\subsubsection{Transforming Information}

"Let us make man in our own image, after our likeness" (Genesis 1:26). This is a bible account of information transformed to you and me up till this time. Men have been reproducing for ages. If the information did not come out the world will never come into existence because there'll be nothing to act upon. Learning is about searching and finding. The early man in the olden days, only had access to raw food, and consumed the food just the way he found it. But when he discovered fire by the stricking of two stones powerfully, he was able to use the fire to heat up raw food so as to make it softer and easier to consume. He made himself roasted meat to eat by the use of the findings h'de made. What the early man found was a means through which energy could be created. Today we use the energy to carry out numerous experiments apart from cooking and roasting meat. From day to day, we need electrical energy to survive, and so many other forms of energy with which we live daily.

Today we have a situation whereby man made products helps him to survive. Where dynamic and very complex products like Aeroplanes, Cars, trains, and different type of machince are being made. Aeroplanes for example are a mechanical simulation of birds. The information gained from the life styles of birds is what was converted through learning into the Planes we have today. The need to derive an end product from the information on ground is why learning takes place. In this case the basic information that can be gained is the process of making, building or constructing(let us make). But for this information to have any value, a transformation needs occur and this transformation can only occur by learning.

\subsubsection{Core Business}

We live in a world of numerous specialities. With the various challenges we face differently, and to be able to combat them all while effectively co-existing with these various specialist, we seriously need to learn to create, invest, protect, detect and make the world worth living.

\subsubsection{Productivity}

Man governs all creatures on earth, he has been endowed with a knowledge, wisdom and understanding that no other animal possesses. Man natually has the ability to take advantage of the numerous resources surrounding him. However to be able to manage the resources around him effectively and for him to fully benefit from these resources, it is important and essential for him to learn how. The need for learning thus arises from the need to be productive.

\subsubsection{Useful Skill}

In some part of the world that refuse learning they are faced with hunger, deadly disease, lack of good housing, lack of clothing, living in extremely devastating conditions. But if they should dispose of the indolence by deciding not to be lazy and accepting education, they stand the chance to gain the knowledge they need to develop their environment and to create the facilities they need to live a much better life. Knowledge isn't an automatic phenomenum. It requires time and patience for it to be aquire. But when possesed, it's absolutely invaluable.

\subsubsection{Fun}

It can be very funny to think that an individual would actually decide to learn for fun. Of all the reasons there are to be learning, fun should be the last... On the contrary, fun happens to a very good reason to learn. Only very talented people happen to be able to make people laugh. They are called comedians. It is also possible to learn how to be a comedian, So long as you love to make people laugh.

In other cases, there's a simple need to keep busy. And an effective way to do that is learning about something that you never came across before.An idle mind is the devils workshop and if learning for the fun of it keeps you from being idle, then it's entirely worth it.

\subsubsection{Global Collaboration}

the eyes need the leg, the stomach need the mouth. Life is interdependent if you don't learn about others you cannot be of benefit to them and vise versal.

"It is probably not love that makes the world go around, but rather those mutually supportive alliances throught which partners recognize their dependence on each other for the achievement of shared and private goals"... Fred. A. Allen

\subsection{Learner's Willingness and Background}

It is always very easy to ride on a willing horse. Like wise if learnershave the urge and willingness to learn, it will be easier for the instructors to work hand in hand with the learner to spin out the gold values in the learner and uncover the hidden potentials in the learner. Some parents have the belief that educating their female children is evil. Invariably when the child has this type of orientation from the parents, the urge for learning will be at the lowest elb. The educational background of the parent also serves as a motivating factor to the learner. If the parent are literates and can find their bearing, they will be able to give the children supportive assistance in doing their necessary studies as expected. But if the parents are illetrates, they'll guide their wards in ignorance, which will see them giving disastrous advices to their children and helping them in negative ways.

\subsection{Facilities Available for Learning}

Up untill this very modern days of technological advancement, some children still have their classroom under trees, inside huts, while others are sitted in well constructed and fully air conditioned classrooms. It is obvious that the attention span of the two types of classrooms will vary and this will affect learning. Students that have access to adequate writing materials, suitable classroom furnitures will pay better attention to learning than students who will be waiting for writing materials from their classmate before he or she can do his work. Students whohave access to computers can use the device 
to boost learning but in a situation where a child does not have an access to electricity supply, what can then enhance the use of computers, Talk more of enhancing his learning ability with a computer.

\subsubsection{Good Feeding}

A hungry man is an angry man is a general saying. If a man is angry when he's hungry, how much less children. Most children are sent to school with empty stomachs due to various reasons. Invariable the attention span of a hungry learner will be long depending on the intensity of the hunger. It is obvious that a child that is able to have break fast before coing to the classroom and has the hope of refreshment during lunch period will be more relaxed in learning. A child who has to beg or do little trading to raise money for feeding will not be fully concentrated.

\subsubsection{Sleep}

Children are expected to have an average of ten hours of sleep everyday. But some children hardly have the required rest. Some run erand aroud for the purpose of making a living. Some watch movies till dead in the night, some will have to wait late in the night for their parents who have busy schedule of work in the office before thy will come and attend to the need of the children. In view of not having adequate sleep there is every likely hood of a hangover whereby the learner can be dosing or sleeping in the class. During the process of sleeping there can't effective learning.

\subsubsection{Packaging of the Learning Materials}

A child who attends pre-school will be exposed to some concept such as alphabet, numbers and colors. The disposition of this type of a child will be quite different from the one that never had any ideas of what opereate in the classroom. If the same learning materials and curriculum is used for both it is obvious that the child that is more informed from the preschoold will understand some concepts faster than those just coming newly to the school.

\section{Influence}

“A power affecting a person, thing, or course of events, especially one that operates without any direct or apparent effort: relaxed under the influence of the music; the influence of television on modern life.

Power to sway or affect hand with the learner based on prestige, wealth, ability, or position: used her parent's influence to get the job" (America heritage dictionary).

In this same manner one person can influence another person in the family circle, community, society and in various organizations positively or negatively.

Looking at the three words explained above one will be able to deduce that leadership plays a vital role in learning process. Leadership influence in learning is basically focusing on the role that leaders plays in imparting skills and knowledge into the learners in achieving the set goal and objectives of the society or organization

The leader is seen as the head of a team or as a driver of passengers bus driving the passenger to an expected destination. Leadership can also be seen as a goalkeeper in the football team, if all the footballers were able to play well against the opponent and the goal keeper is not competent the team will not be able to achieve their desire. Leaders have major functions of directing at the same time influencing for change.

Influence follows the steps of Observation, fascination and perseverance.

Education is the key to social and economic development, it paves the way for more and sustainable societies that value knowledge, promote culture of peace, celebrate diversity and defend human rights. Despite the various recent progress toward education millions of children, youth and adult world wide lack access to good and quality education and the various advantages of education.

'The educated differ from the uneducated as much as the living from the dead' (Aristotle, on education) "There is a difference between interest and commitment. When you are interested in doing something, it is only when convenient. When committed, you accept no excuses, only results” (Kenneth Blanchard)

A good leader is seen by what he does. They don't demand respect like the authoritarian who enforceshimselve on the people. Instead he works to earn this respect because he understands the need for ethics and also respects the face that his followers deserve his respect for the little effort the put into ensuring progress for the whole group. A leader deserves to have followers if he or she has earned recognition. Authority alone is no longer enough to command respect. A leader sees things through the eyes of followers. A leader puts himself or herself in the shoes of the follower and helps make their dreams come true.

A leader does not say, "Get going!” Instead, a leader says "Let's go!" and leads the way. With the global advancement our world has experienced till now, we still have some school leaders who run after students like cat and mouse, not actually leading the way, but forcing and pushing them like robots when they are supposed to be aiding them carefully and going hand in hand with them to acertaining that their common goals and objectives are reached. (6)

A leader does not walk behind with a whip, but is out in front with a banner. Leaders who reduce his followership to an animal is regarded as more of the animal than the followers. Looking at the followers with a positive mind of trust and guiding around their dream will yield more positive result in learning, it provide more room for creativity

In the past leader assumes that followers are working with the leader, but any leader with such an impression in this modern day of science and technology is a complete failure in himself or herself because the leader will be stagnated hoping that the follower cannot have mobility of labor opportunities are wide open worldwide for creative learner so learners are not for the leader but for the success of the group and individual achievement

A leader who glorifies in team spirit will record more of success than those who claim that they are all in all. The act of leaders duplicating himself or herself in others can only be achieved when the leader sees himself or herself as servant of the followers and not as rubber stamp.

A leader is a person builder, a builder can never start construction from the roof he will have nothing to sustain the roof. Leaders who actually want to help followers 
grow big must be passionate about the foundation and the progressive growth of the followers because the more big people there are, the stronger the organization. The more a leader holds others down the worst for the leader, when he will need a lift up he will found all that are supposed to support still down and will eventual find himself in the position he enjoy keeping others. A leader reaches out his or her hand to help followers scale the peaks.

Around 1984 when I had my first baby I was traveling to my state for the week-end with the small baby in our car. We ran into a political crisis when we entered my stated. The hundreds of people in front of us and the fatal and disturbing damages we had seen on the way, the assurances facing my family was death. We were surrounded by fully armed gunmen and others with their various arms and amunitions. As I wind down the window of the care, one of my old students shouted my maiden name and stoped those who wanted to set the car a blaze. To my amusement they turned around to congratulate me for the new baby and gave me tips on how to avoid disasters. When we arrived home late that night my parents found it difficult to understand that this group had piloted us out of this political riot without hurting us.

I simply reminds and shows me how a good leader can easily influence the decisions and opinions of his followers, not just by dishing out instruction, but by those very little actions of modesty and love.

Influence as mentioned above is "power to affect". For example if you are the type of person that likes to listen to music when you chose to relax, you'd most likely tune to a more solemn track rather than a screaming hard rock or a funky hip hop beat. By doing this, you'd forget about the so many things that bother you, and you'll be focused on enjoying your music. The influence this music track has on you isn't imposed in any means, only the sence of hearing transmit the melody to the expected nerves and calm down the individual. Influence is a social phenominum of a person, position, family, community, society wealth or ability. It is totally impossible to influence anybody even if you have all the social characteristic above and you lack understanding.

Factors that aid influence: there are various factors that can help a leader to vinluece which will be enumirated below:

Understanding: "Can two walk together except they be aggreed?” Will a lion roar in the forest when he hath no prey? (Amos 3: 3-4) KJV. It is totally impossible for two to consumate marriage if there is no agreement. The two people that must go into marriage now must understand each other socially, emotionally, finacially, culturally and even in language. When I started discussing about learning, I mentioned that in a family that the father is the leader.

For a couple to finally agree to get married, the man would have to propose to the lady, and if the lady feels she's in confomity with the man's proposal, she accepts, and if she's not, she rejects his proposal. The type of friendship that will result into marriage would first and foremost have to pass the test of understanding.

An educational leader can never influence any student effectively if he refuses to understand the students. This is one of the major reason why counselling is very important.

I once had a boy in my environment that was deaf and dumb, I noticed that this boy was at all times alone. I decided to move closer to him to be able to understand the reason he chose to be alone at all times. In my attempt to get closer to him, I discovered his hearing and speaking disabilities. I over time developed a very strong passion to help him. I was so despirate and passionate about this young boy that I did not care about how much it would cost me. I started searching for resources that will help me in understand sign-language. Suprisingly for me, before the end of that school year, I understood sign laguage effectively and when people needed to communicate with him, they often came around to seek for my assistance in interpretation. I can never forget that experience, I loved it, but most importanly I loved the fact that my passion could drive me to making such a difference in the life of a disabled young boy. This boy today is a successful family man, who has gained a strong reputation as a result of his academic exploits.

\subsection{Communication}

Communication is the act of conveying information or news, it includes verbal and non verbal communication.

Wikipedia defines communication as the activity of converying meaningful informantion. Communication requires a sender, a message and an intented recipeinct( receiver). In the computing word we have input, process, and output. Communicaition is not complete if the reciever did not understand the concept(message).

My first time at Henri Coanda International Airport Otopeni Bucharest, Romania, I was lost in communication when I heard the public address system say "Doamnelor si Domnilor”. I couldn't interprete the meaning, so I had to ignore the annoucement. The annoucment was important but not relevant to me because of communication problems. A leader must be absolutely effiecient in communicating. To be efficient in communicating you must speak like your follower, prepare to listen like your follower and send out response like the native speaker.

I was in Bulgaria sometime ago, and I missed my way. I decided to ask with the little knowledge of romanian language I had in an attempt to find my bearing. It was shocking to find out that their language was an opposite of what it described. If they pointed to the left they meant right. We went in the wrong direction until we arrived at a sign that was in a language we understood, and we then found our way. It was interesting to learn the difference Bulgarian language had from all the languages I knew.

The lack of understanding was what caused us all the problems we had.

1. Verbal communicaiton involves face to face interaction between people or dialouges in general. The participants in the dialouge must understand their language for a positive response to be received from the listener.

2. Non verbal communication includes the use of body gestures in expression such as eye contact, facial expression, mode of dressing and symbols. E.g like road signs for road users. Understainding the signs will help the respondent to give necessary feedback. An example of non verbal language is sign language for hearing impared people.

\subsection{Welfare or Care}


The well being of the followers is of great importance to the followers. If all the students in a class are indisposed and are in hospital beds, the teacher will only have the four walls of the classroom to lead to no where. Understanding the problems of the students, taking sides with them and showing emphaty by assisting in solving their problems in a situations that are affordable by the leader is invaluable in terms of influencing followers. This will serve as a motivating factor for the student to pay more attention to their teacher.

It is understood that when a student likes a teacher, he will be able to pay more attention to the teacher's lessons. When you care for them as expected you are bound to get positive feedback.

\subsection{Change Possibilities}

It is always easier for people to stay glued to what they are used to but in a polite manner to be able to adapt to new things. Chris Witt mentioned that argument should be avoided because the person you defeate in an argument today may be the person whose coopereation you'll need tomorrow. The more you prove your followers wrong the harder they will refuse you. In mathematics you proof your case but in social research you only show evidence. The basic principles of evidence are exploration, description and explanation.

A typical experience of mine have shown that most people in Romania have never been to Africa. I am from Africa and I'm in a very good postion to describe the situation of electricity in my country as epileptic supply.

However, on stating this fact to some, I received reactions of shock and disbelieve, which is a normal response because they have never experienced such in their own countries.

For progress to be made, Individuals can decide to visit Nigerian and spend a week or two there to explore. During the process of exploration, influence will gradually be taking place, the concept of epileptic power supply will slowly but surely settle in with person's experience. The epileptic can be obsolate with time if the government see reasons to illuminate everywhere. Which ever ways, the experience would be one to hold on to for a very long while.h

\subsection{Herd Attitude}

A clergyman can be refered to a shepherd, which is taking from Jesus' example by leading his followers. Shepherd watch over sheep and take care of them. The sheep will follow the shepherd because they already know him. Teacher should copy the attitude of a shepherd to be able to influence effectively. "He knows his sheep and the sheep also know him”. Know your students by name, atttitude, temperament and some personal percularity. This will convince the follower that you are actually interested in him.

\subsection{Timing}

Talking to someone when he is tired or willing to go to sleep may be a wasted effort. When the follower is willing to pay attention without distraction in a condusive atmosphere in another way of influencing people. Therefore the leader must put into serious consideration the time in which he choses to take leadership actions towards his followers.

\subsection{Summary}

Great people of influence are not measure by physical starture but the impart they made in people lifes You can rule for hundred years yet have no follower.

"If your imagination leads you to undestand how quickly people grant your requests when those requests appeal to their self-interest, you can have practically anything you go after".... Napoleon hill

"If you want to be incrementally better, be competitive. If you want to be exponentially better, be cooperative”... Unknow

\section{References}

[1] Burke Johnson, Larry Christensen fourth edition (Educational Research Quantitative, Qualitative and Mixed Approaches) Sage Publication Washinton D.C.

[2] Peter G. Northouse Second Edition ( Leadership Theory and Practice) Sage Publication, Inc USA.

[3] Jerome Bruner. (The Culture of Education) Harvard University Press Cambridge,Massachestts London, England.

[4] Mission to Learn http://www.missiontolearn.com/2009/05/definition-of-learning/.

[5] Leadership development methods and tips http://www.businessballs.com/leadership.htm.

[6] How Leadership Influence Student Learning http://www.cehd.umn.edu/carei/Leadership/ReviewofResearch.pdf 